\title{
COPY-CAT FEEDING OF HOUSE SPARROWS
}

FRANK SWITZER, 1301 Shannon Road, Regina, Saskatchewan. S4S 5K9

I don't know many bird watchers who would take the time to observe some of the feeding habits of House Sparrows. Well, I didn't start out to intentionally study the eating habits of the House Sparrow. You might say that these observations started with morning coffee on the patio.

House Sparrows are not my favourite birds. Growing up on a farm almost seems to dictate that this bird be viewed as "pesky vermin" that should be under threat of death on a continual basis. I did not find the continuing task of plugging farm building holes as offering fulfilling and meaningful productive activity. In spite of all efforts, there would come a day when a granary was opened and the over winter roost of a flock of this pesky bird was abundantly evident. The barn hayloft was another impossibility and each year there seemed to be a strip of peeling paint on the combine when it came out of the machine shed. To add insult to injury newly sprouted lettuce was harvested while at the sparrow mouthful size, just when anticipation peaks for that first feed of something homegrown, fresh and green.

Thirty years of eight-to-five somewhat dull memories of youth and House Sparrow intolerance. Indeed, there is a somewhat grudging admiration for a creature that endures the heat and drought of summer and the frigidness of winter along with you. And, that brings us back to a summer morning coffee on the patio. The apple tree is in full bloom, the air is pungent and a flock of Cedar
Waxwings descends. The apple tree is being ravaged, waxwings are feeding voraciously on the petals. Of course, this activity is probably helping to enhance the fruit crop since pollen is being liberally spread around. Then, quite unobtrusively several House Sparrows quietly move in and seem to become very interested in the feeding antics of the waxwings. After a few minutes the sparrows begin tentatively tearing petals from blossoms but not eating them. Instead they pluck the petals and discard them, continuing to tear the stamens and then the ovary leaving only the flower stem. They then move on to the next. The whole process stops when, in an excited flurry, the waxwings depart for a tree in the neighbouring yard.

A few mornings later, with my coffee in hand and binoculars within reach, I watch a Northern Oriole visit the apple tree and start to deftly insert its beak into the rolled up leaves of the Leaf Roller Moth to extract the tasty larva from within. The oriole is very deft at this task and successfully visits several rolled leaves. Again the sparrows appear and become very observant. The sparrow's first attempts are unsuccessful as first one end of the leaf roll is tried and then the other. It appears as if the grub inside moves far enough to escape the probing beak. However, the tantalizing morsel inside is not to escape for long, for soon the leaf roll is torn apart and the worm consumed. The sparrows then move from rolled leaf to rolled leaf, tearing them apart in turn, to get the delicacies inside. 
These two incidents started my curiosity. Was there indeed a degree of copy-cat feeding as a part of House Sparrow make up? The observation quest was on.

Most bird books and field guides in my library do not provide detailed information on the feeding habits of specific species. They treat feeding habits in a general way, while giving details on appearance, voice, nesting, habitat and range. Primary observation is the course one must follow.

I began to note the occurrences of House Sparrows in company with other species. During the summer, more often that not, when robins were feeding on the lawn or in the garden, there would also be sparrows. Sparrows never seem to try digging anything out of the ground as do robins. However, they did seem to find something to their liking as surface finds in the garden and they invariably flushed moths out of the lawn grass, giving chase and catching most. If the lawn grass contained significant numbers of these small moths, sparrows would continue to return and randomly hop around to flush more moths.

The next good example of copy-cat feeding I saw while watching Eastern Kingbirds feeding on grasshoppers. My attention was drawn to this activity when a pecking sound was heard on the top of the back fence. Beyond the fence is a park area that opens onto cultivated fields across the Trans-Canada Regina bypass. With inflights from highway ditches and fields, the park grasshopper population can rise significantly during July and August. This readily available food source coincides with hungry Eastern Kingbird nestlings. I have watched repeated kingbird grasshopper captures. The kingbird starts its hunt by flying in to perch on the fence comer. This vantage point is used to survey grasshopper activity below. A darting swoop low to the grass usually results in a capture and then a return to the fence. The next step in the process is to hammer the wildly kicking grasshopper on the boards knocking off legs and wings. When the grasshopper is satisfactorily bashed into submission, it is then taken to feed the nestlings.

Enter the House Sparrow. Sitting on the fence nearby it appears to carefully watch the kingbird technique. Sparrowcopied kingbird activity follows with great leaping, fluttering bounds after a grasshopper that escapes with a prolonged flight following two or three jumps. The sparrow returns with the arrival of the kingbird. However, this time the sparrow spies the dropping grasshopper legs and wings and it descends to the base of the fence to pick up and consume these unwanted parts. Soon several sparrows are combing the garden and the grass under the fence corner to pick up grasshopper parts.

The next observation episode also involves copying kingbird feeding techniques. Each year the apple tree drops several pails of unripe apples on the lawn below. These apples are picked up before each mowing and dumped into the compost box by the back fence gate. Here the apples mellow until a state of decay attracts flies and yellow-jacket hornets. This abundance of flying insects is definitely attractive to Eastern Kingbirds. They arrive to perch on the back fence from whence they drop down to pick a flying insect from the top of the apples then return to the fence to consume the morsel. If the catch is a large fly there is a bit of bill manipulation, then the insect is consumed. If, however, the captured insect is a hornet the procedure is to do the bashing-in-the-fence routine until a suitably pulpy state is achieved; then, and only then, is the morsel consumed.

House Sparrows copy-cat feeding in this case is always just that, copy-cat feeding. It is fairly accurately copied 
right down to the hornet bashing before consumption. What I found surprising was that, when the kingbird finished feeding at the compost box, the sparrows also left, in spite of an abundance of flies and hornets remaining.

Now, I know, one summer's observations do not make a study of House Sparrow feeding behaviour. However, I found these observations most enjoyable and in the process I learned something about a creature that I all too often either take for granted or view with some disdain and will always consider a rather messy pest.

The fine spring weather of 1991 April brought forth the chair on the patio and the moming coffee. It sure is great to once again share the backyard with northward migrants. A male robin is acting territorial. Since earthworms are still scarce the robin territory includes apparent exclusive feeding rights in the Russian Olive at the back fence. The robin's olive consumption is quite selective. First a likely cluster of silvery berries are plucked and rolled around in a bill-jiggling process. For whatever reason several are discarded and dropped to the ground before one is finally con- sumed. The process is repeated for the consumption of about three or four fruits.

After a territorial disagreement with another male robin and a singing tour of territory, the resident male returns to the ground beneath the Russian Olive tree. Several olive pips are ceremoniously regurgitated, now stripped of the silvery green outer flesh. The fruit previously dropped to the ground is reexamined in a selection process and again the three or four berries are consumed. This selection activity has been keenly observed by three House Sparrows. When the robin leaves they descend to the ground and begin billing the olive fruit. A House Sparrow's bill is evidently better designed to strip the tough outer coat from the olive fruit. However, this tough dry skin and pulp is discarded. The now cleaned pip is billed further but is still too large to consume and is also dropped. Several fruit are thus dealt with by each House Sparrow before a decision is made to abandon this activity as a potential food source. The sparrows depart and in due course the robin returns to make a selection of Russian Olive berries based on criteria known only to him.

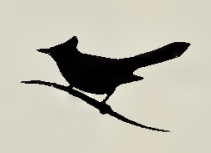

Because their caterpillars eat milkweed, Monarch butterflies are considered to be distasteful, even poisonous, to birds. However, at wintering sites in Mexico, Monarchs are the main food of Black-headed Grosbeaks. Some milkweed are less poisonous than others and the butterflies become less toxic with time. Scott. 1986. Butterflies of North America. Stanford University, Stanford.

Spiders are the major predators of butterflies. R.M. Pyle. 1984. Audobon Society Handbook for Butterfly Watchers. Scribner's, New York. 